\title{
1. State jurisdiction in international law: complexities of a basic concept Alexander Orakhelashvili
}

\subsection{MEANING OF STATE JURISDICTION}

Jurisdiction is the principal tool of the assertion by states of their public and sovereign authority, possessing which distinguishes the state from the entities that operate under private law. Any exercise of public authority by the state, whether prosecuting a crime, expropriation of property, regulation of trade or taxation, or anything else, and whether lawful or unlawful under international law, involves the exercise of state jurisdiction. The exercise of state jurisdiction takes place in the context that rights may be acquired by individuals and other private entities outside the forum state's boundaries, which is a matter that could fall within the jurisdiction of more than one state. Similarly, the interest of individuals and corporations could also vary: some national legal systems could provide a better procedural standing, more effective remedies, or better access to the object of the relevant litigation, or otherwise confer advantages attractive to litigants and influence their choice as to in which legal system they should pursue litigation.

Under public international law, states are independent from, and unsubordinated to, each other. Absent special agreements, there is no centralized mechanism or arrangement for distributing jurisdictional entitlements among states, or determining their priority. Instead, jurisdictional relations operate, as it were, on an inter-state interactional plane. In the first place, there is an initial entitlement of, or claim by, the state to exercise jurisdiction over a particular person or matter. Then, there is an issue of whether that jurisdiction will be recognized as lawful, or otherwise accepted and accommodated, by other states, and accorded any effect within those states' territories, with or without inherently prejudicing the initial lawfulness of that exercise of jurisdiction. These factors are relevant not just in relation to controversial cases of the exercise of jurisdiction, but also in relation to most obvious and undisputed cases of state jurisdiction. This is so, if for no other reason, than because whichever kind of jurisdiction is asserted by the state, territorial or 
extra-territorial, the reach of that assertion is bound to be limited to the territory of that state.

There is no analytical or practical limit on the range of acts through which state jurisdiction can be introduced or asserted: any legislative, executive or judicial act of the state will in principle do. One way through which state jurisdiction can be asserted relates to national systems of private international law. Any national enactment of a 'conflict of law' rule in essence constitutes the relevant state's unilateral determination of the scope of its laws and, this way, inevitably constitutes an assertion of jurisdiction. According to Dicey, in this area an English court has to answer two questions, one regarding whether it has jurisdiction to determine the cases of the relevant kind; and, if the first question is answered in the affirmative, what law must be chosen to apply to those cases. ${ }^{1}$

International comity accounts for the development of some patterns in this area. On the one hand, comity could lead the forum state to recognize and apply foreign private laws, thereby in effect recognizing the competence of the foreign state to legislate with the extra-territorial effect. Curiously enough, the application of foreign laws in the conflict of law framework involves both the exercise of the territorial jurisdiction by the forum state, and the recognition by that state of (at times extraterritorial) jurisdiction of the state that authors the foreign rule in question.

On the other hand, as Savigny observed in the nineteenth century, no state can require the recognition of its laws beyond its own territory. ${ }^{2}$ By and large English courts have taken the same approach. To illustrate, the UK House of Lords emphasized in Government of India v Taylor that foreign public and revenue laws would not be recognized or enforced in the English legal system. ${ }^{3}$ What we see here is the obvious manifestation of a territorial jurisdiction of a state, perfectly lawful under international law on territoriality grounds, yet not given any effect by another state, without this inherently amounting to the United Kingdom taking the

1 A.V. Dicey, A Digest of the Law of England with Reference to the Conflict of Laws (1896), pp. 1-2; see also A. Lowenfeld, 'The Limits of Jurisdiction to Prescribe' in A. Lowenfeld, International Litigation and the Quest for Reasonableness (1996), p. 15 at 16.

2 Cited in M. Akehurst, 'The Doctrine of Jurisdiction in International Law' (1972-73) BYIL 219.

3 Government of India v Taylor [1955] AC 451. 
position that the particular assertion of foreign jurisdiction involving the operation of those public or revenue laws is unlawful under international law.

As a flipside, English courts will not enforce contracts that could lead to the violation of foreign law in the foreign state. ${ }^{4}$ This is an implication of international comity. ${ }^{5}$ The way comity works, and influences litigation outcomes, depends on what kind of prohibition has been enacted in the foreign jurisdiction and whether, then, English courts will consider obedience to that foreign prohibition to be dictated by comity. ${ }^{6}$ The ultimate meaning and impact to be accorded to comity is thus dependent on its articulation and recognition in the forum state.

As Husserl suggests, 'Foreign law by itself is powerless to operate beyond the boundaries of its own territory - as is also the domestic law of the forum'. ${ }^{7}$ Moreover, as Lorenzen has emphasized, the assertion of territoriality, for instance by subjecting contracts to the law of the place of their performance, essentially asserts that territorial law as extraterritorial. ${ }^{8}$

This demonstrates that jurisdiction is much more complex than its initial territorial basis from which state authority initially derives its existence, more interaction-focused and dynamic, more dependent on contexts premised on state choices and the reconciliation of those choices. 'Territoriality' as much as 'extra-territoriality' thus becomes a matter of degree and characterization. It is true, as Niboyet observes that, 'As territoriality involves the least sacrifice for each nation, it will be the

4 Regazzoni v KC Sethia (1944) Ltd [1958] AC 301.

5 See also Driscoll [1929] KB 470 at 510 (per Lawrence LJ): 'I am clearly of opinion that a partnership formed for the main purpose of deriving profit from the commission of a criminal offence in a foreign and friendly country is illegal, even although the parties have not succeeded in carrying out their enterprise, and no such criminal offence has in fact been committed ... The ground upon which I rest my judgment that such a partnership is illegal is that its recognition by our Courts would furnish a just cause for complaint by the United States Government against our Government (of which the partners are subjects), and would be contrary to our obligation of international comity as now understood and recognized, and therefore would offend against our notions of public morality'.

As was discussed in Kleinwort [1939] KB 678 at 688-9 (per Branson J).

7 G. Husserl, 'Public Policy and Ordre Public' (1938) 25 Virginia LR 37 at 66 .

8 E.G. Lorenzen, 'Territoriality, Public Policy and the Conflict of Laws' (1924) 33 Yale LJ 736 at 743-4. 
easiest principle on which to agree'. ${ }^{9}$ Yet this is still subject to the principle that under public international law no state owes another state a duty to recognize the effect of its legislation - territorial or extraterritorial, public or private - in its own courts; and the approach which English courts have declared as embodied in India $v$ Taylor is in principle (and subject to treaty obligations to the opposite effect) an option open to any state to elect, either through declining to recognize foreign law, or to use public policy or any comparable domestic doctrine to offset the relevance of that foreign law.

At the crossroads of public and private international law, we can identify the basic position that the laws of the state have no inherent force beyond that state's territory. A lawful exercise of territorial jurisdiction, premised on the exercise of core sovereign powers, could be denied the relevant transnational effect in another state, while jurisdiction that can in principle be contested could, at the end of the day, be given such effect via the route of private international law.

Therefore, the view that the private international law aspects of jurisdiction and applicable law are inherently determinative of the legality of state conduct as a matter of public international law could not be tenable. For any position taken as a matter of private international law is, in essence, a position unilaterally taken by the state. Such position cannot be regarded as self-judging as to its ultimate legality. To the contrary, public international law itself determines the ultimate legality and limit of private international law actions in the transnational field. Public international law is therefore a governing framework for private international law matters, not their mirror-image.

And in some cases, there may be public international law limits on the foreign state's jurisdiction and on the permissible ambit and reach of its laws. The forum state should treat it as subject to such limitation. This was made clear by the English Court of Appeal in Al-Jedda, where nationality laws of Iraq had to be applied in the United Kingdom subject to the requirements of international humanitarian law treaties binding on the United Kingdom. ${ }^{10}$

9 J.-P. Niboyet, 'Territoriality and Universal Recognition of Rules of Conflict of Laws' (1942) 65 Harvard LR 582 at 586, 595.

10 Hilal Al-Jedda $v$ Secretary of State for the Home Department [2012] EWCA Civ 358, CA (Civ. Div.). 


\subsection{JURISDICTION IN THE CONTEXT OF PUBLIC INTERNATIONAL LAW}

Some basic rules and standards of public international law as to the jurisdictional behaviour of states, especially in relation to the exercise of extra-territorial jurisdiction, raise issues as to those fundamental principles that govern the relations between states, especially the principle of non-intervention. For instance, Oppenheim, presumably illustrating a standard that could form the core of both comity and of international law on the matter, suggests that:

Personal Supremacy [over nationals] does not give a boundless liberty of action ... a State is prevented from requiring such acts from its citizens abroad as are forbidden to them by the Municipal Law of the land in which they reside, and from ordering them not to commit such acts as they are bound to commit according to the Municipal Law of the land in which they reside. ${ }^{11}$

But there also may be many matters that are not subject to strict prohibitions in the relevant foreign country - things and matters in relation to which the forum state may just be asserting its own jurisdiction extra-territorially. Does asserting such jurisdiction per se amount to the 'ordering' Oppenheim speaks about? To give an example, under the 1980 British Trading Interests Protection Act, enacted in response to the assertion by the US courts of extra-territorial jurisdiction in relation to economic matters, seen by the British government as excessive, could the United Kingdom be seen as wrongfully ordering its subjects and residents not to do certain things which they would be obliged to do in the United States, namely, comply with the US judicial decisions rendered within the US jurisdictional realm?

There might be a debate as to whether the 1980 Act was itself asserting the extra-territorial jurisdiction, and as to whether it did so rightfully as a reciprocal measure, and the outcome probably is that it was not an exercise of a far-reaching extra-territorial jurisdiction, instead complying with the territoriality and nationality jurisdiction requirements. Blocking orders were enforceable only in respect of the conduct within the UK

11 L. Oppenheim, International Law (2nd edn, 1912), vol. I, p. 296; D. Bowett, 'Jurisdiction: Changing Pattern of Authority over Activities and Resources' (1982) 53 BYIL 1 at 7-8 also speaks of the law of the state of nationality requiring the individual to perform conduct illegal under the loci delicti commissi. 
territory, or in relation to the conduct of UK citizens anywhere. ${ }^{12}$ But even in that case, an example is furnished of one state obstructing the operation of another state's laws within the latter's realm, even without a far-reaching extra-territorial assertion of jurisdiction being expressly involved.

Section 6 of the 1980 Act included provisions on the recovery of 'non-compensatory' elements of US-awarded damages. They did not require proof of the UK jurisdiction over, or of the unlawfulness of the US jurisdiction in, the relevant matter. Instead they presumably infringed on the US jurisdiction exercised under its most traditional headings. The conclusion is advanced that the use of section 6 would have violated US sovereignty. But speaking more broadly, the economic sovereignty argument cuts both ways. ${ }^{13}$ So also, presumably, would the non-intervention duty in relation to economic policies that the relevant state chooses to exercise be violated. Akehurst similarly observes that the state's economic policy may be expressed either in directing economic entities to do certain things or leaving them free to do as they think best. In either case, another state would break international law by requiring its nationals in the first state to act in a way thwarting that state's economic policies. ${ }^{14}$ Again, such national freedom to direct private entities accordingly is available to any state.

Moreover, unless an obvious case is made as to the unlawfulness of the antecedent US extra-territorial jurisdiction to be exercised by US courts which case would be difficult to make anyway - could it be a mere matter of appreciation as to whether the 1980 Act was trying to obstruct what was within the rights of US judicial authorities? Even in relation to 'ordering' British citizens to do or not to do certain things, that argument could (in conceptual and analytical terms) be sustainable, if the relevant British citizens had been placing themselves within the US jurisdiction through their presence and business.

And while in the absence of a treaty states are not obliged to enforce each other's economic policies or court judgments, ${ }^{15}$ would it not be more analytically convenient to view this entire matter through the prism of parallel state autonomies, especially in terms of a state's own system of 'conflict of law', rather than through the prism that deals with the inherent lawfulness of foreign jurisdiction? Perhaps, then, the greatest

12 A.V. Lowe, 'Blocking Extra-territorial Jurisdiction: The British Protection of Trading Interests Act, 1980' (1981) 75 AJIL 257 at 274-5.

13 Ibid. 280.

14 Akehurst, n. 2 above, 189.

15 Lowe, n. 12 above, 276-7. 
impact of the 1980 Act was to turn what was already open to the British government, as a matter of both international and domestic law, into a mandatory matter.

And then, as Sir Robert Jennings has illustrated, a more difficult question might arise in the much commoner situation where there is no direct collision between the local and the external laws, but where, nevertheless, the act which offended against the external law was perfectly lawful in the law of the place where it was done'. While in such cases the extra-territorial jurisdiction should not normally be exercised, Jennings suggests that this principle cannot operate as an absolute one. There may be cases where the state's laws are unreasonably lax in providing safeguards against the use of its territory for the fermenting of revolutionary disturbance among its neighbours. A neighbour state should be able to exercise extra-territorial jurisdiction in such cases. ${ }^{16}$

\subsection{CONFLICTING JUSTIFICATIONS OF STATE JURISDICTION: SOVEREIGNTY-DRIVEN AND INTEREST-DRIVEN APPROACHES}

According to authors such as Mann and Jennings, state jurisdiction is an extension of its sovereignty. Mann suggests that:

International jurisdiction is an aspect or an ingredient or a consequence of sovereignty (or of territoriality or of the principle of non-intervention ... : laws extend so far as, but no further than the sovereignty of the State which puts them into force nor does any legislator normally intend to enact laws which apply to or cover persons, facts, events or conduct outside the limits of his State's sovereignty ... jurisdiction involves both the right to exercise it within the limits of the State's sovereignty and the duty to recognize the same right of other States. ${ }^{17}$

Jurisdiction involves 'a State's right to exercise certain of its powers ... like all attributes of sovereignty this liberty is subject to the overriding question of entitlement'. ${ }^{18}$ Jurisdiction is generally associated with the

16 R.Y. Jennings, 'Extra-territorial Jurisdiction and United States Antitrust Laws' (1957) 33 BYIL 146 at 151-2.

17 F.A. Mann, 'The Doctrine of International Jurisdiction Revisited after Twenty Years' (1984) 186 Recueil des Cours 9 at 20.

18 F.A. Mann, 'The Doctrine of Jurisdiction in International Law' (I-1964) $111 R d C 1$ at 9 (emphasis in original); R. Jennings and A. Watts (eds), Oppenheim's International Law (9th edn, 1992), p. 456. 
concept of sovereignty and a state's personal and territorial limits. ${ }^{19}$ Furthermore, 'the connection between jurisdiction and sovereignty is, up to a point, obvious, inevitable and almost platitudinous, for to the extent of its sovereignty a State necessarily has jurisdiction'. ${ }^{20}$ Bowett expresses a similar position. ${ }^{21}$ All in all, 'the concept of territorial sovereignty has become a useful metaphor for a system of communication' ${ }^{22}$

Under this approach, the principle of sovereignty could potentially be seen as a ready-made guide to enable us to assess the legality or propriety of any jurisdiction exercised by the state territorially or extra-territorially. The regulatory relevance of the concept of sovereignty is further suggested, for instance, 'by acknowledging that the right to control certain elements of economic activity is an essential component of sovereignty, it may be possible to identify a legal principle "economic sovereignty" - to guide the resolution of jurisdictional disputes'. ${ }^{23}$ Especially in the context of UK-US jurisdictional controversies regarding the exercise of extra-territorial jurisdiction, Lowe has also proposed to devise a more general theory of economic sovereignty that will support the superstructure of jurisdictional rules and relations. ${ }^{24}$

That there is an initial systemic link between the sovereignty of a state and its ability to exercise jurisdiction as cognisable by international law is undeniable. But how far the connection between these two elements could be taken, to assess the merit of specific exercises of jurisdiction, is less certain. To some extent, these matters constitute an issue of inter-state relations that is analytically antecedent to the issue of jurisdiction, which could reinforce as well as compromise various visions of territoriality. Thus, according to Oppenheim:

a State can only require respect for its laws from such aliens as are permanently or transiently within its territory ... No right for a State to extend its jurisdiction over acts of foreigners committed in foreign countries can be said to have grown up according to the Law of Nations..$^{25}$

19 Mann, n. 18 1bove, 9; R.Y. Jennings, 'General Course of International Law' (II-1967) RdC 516.

20 Mann, n. 18 above, 22; Jennings and Watts, Oppenheim, n. 18 above, 457.

21 Bowett, n. 11 above, 1.

22 H.G. Maier, 'Jurisdictional Rules in Customary International Law' in K. Meessen (ed.), Extraterritorial Jurisdiction in Theory and Practice (London: Kluwer, 1996), p. 64 at 65.

23 A.V. Lowe, 'The Problems of Extraterritorial Jurisdiction: Economic Sovereignty and the Search for a Solution' (1985) 34 ICLQ 724.

24 Lowe, n. 12 above, 281-2.

25 Jennings and Watts, Oppenheim, n. 18 above, 204. 
This thesis purports to impose a preconceived limit on the admissible exercise of state jurisdiction, and leaves the state of affairs uncertain in relation to the bulk of issues, such as subversive activities, or forging currency or other economic subversion.

Another extreme following of the territoriality cliché is proposed by Judge Moore, in his dissent in the Lotus case, to the effect that 'The principle of absolute and exclusive jurisdiction within the national territory applies to foreigners as well as to citizens or inhabitants of the country'. ${ }^{26}$ The initial territorial sovereignty basis for the legitimation of jurisdiction thus becomes the ultimate limit of that jurisdiction. And it is bound to do so, if the initial legitimation advanced by Judge Moore is so strict and carved in stone. This makes clear that the sovereignty-driven view of jurisdiction does not account for the most obvious nationalitybased instances of jurisdiction, and thus not only furnishes us with a preconceived cliché but also undermines the concurrence of various jurisdictions.

While it is true that any exercise of jurisdiction is an exercise of sovereign power, and that jurisdiction cannot be exercised without some public or sovereign powers being involved, this does not fully account for the basis on which the relevant exercise of jurisdiction rests, let alone for an ultimate limit, up to which the assertion or exercise of jurisdiction can be taken.

In fact, as Katzenbach observed, the sovereignty-centred approach does not sort these dilemmas, because the sovereign command is behind both the forum's rule and the foreign vested right. ${ }^{27}$ The sovereignty of the state exercising jurisdiction in principle militates in favour of jurisdiction being taken as far as that state would like, while the other states' sovereignty would militate against the exercise of jurisdiction by the first state without those other states' consent.

For ascertaining the ambit of jurisdiction, territoriality is, at most, merely a conceptual starting-point, not the ultimate guide. For, as Brownlie has observed, states are entitled to enforce their interests on a basis other than territoriality, if a substantial connection is demonstrated with the relevant acts and events. ${ }^{28}$

26 S/S Lotus (France v Turkey) PCIJ Series A, No. 10, 28, Judge Moore, Dissenting Opinion, 69.

27 N. de B. Katzenbach, 'Conflicts on an Unruly Horse: Reciprocal Claims and Tolerances in Interstate and International Law' (1956) 65 Yale LJ 1087 at 1115 .

28 I. Brownlie, Principles of Public International Law (OUP, 2008), p. 299. 
It is right to say that the sovereign is territorially based and can enforce its laws only within its own boundaries (barring exceptions such as consular jurisdiction firmly consigned to textbooks of legal history). But it would be too presumptive to suggest that the state's entitlement to regulate the conduct of its nationals abroad, or even to prescribe rules as to its security and protection, is less sovereign than, say, prosecution of an act of theft perpetrated within that state's territorial boundaries. ${ }^{29}$ Conversely, and while ordinarily states are supreme in their own territories, it is also the case that, as Akehurst observes, 'it is impossible to hold that locus regit actum is a mandatory rule', or that the application of lex rei sitae is a requirement under international law. Convenience and public international law requirements are not the same thing. ${ }^{30}$

The position that states can assert or exercise jurisdiction only in relation to matters and persons within their sovereign realm is unsustainable as a general theory of jurisdiction under public international law. It is not obvious at all that the boundary between national jurisdictions runs in the same place as the boundary between national sovereignties. It can be said with certainty that there can be no more than one sovereign over a particular territory. It could not be said with the similar certainty that any single person or matter should always and exclusively be subject to one single sovereign power. In other words, sovereignty does not do the same job in relation to the boundary between jurisdictions as it does in relation to the boundary between state territories. Territorial supremacy of the state does not determine any template for the ultimate reach of, or limitations on, that state's jurisdiction.

The confusion about the central importance of the territoriality approach is due to the failure to distinguish between the two things in the way in which they were distinguished by the Permanent Court of International Justice in the Lotus case. As the Court emphasized:

the first and foremost restriction imposed by international law upon a State is that - failing the existence of a permissive rule to the contrary - it may not exercise its power in any form in the territory of another State. In this sense jurisdiction is certainly territorial; it cannot be exercised by a State outside its

29 The magnitude of an interest is not always measured through its relation to territoriality. W.E. Hall points to the 'fact that maintenance of control over the men and ships of his mercantile marine is an object to a foreign sovereign of deeper importance than the assertion of jurisdiction on every occasion can be to the territorial authority', W.E. Hall, A Treatise on Foreign Powers and Jurisdiction of the British Crown (1894), p. 6; ibid. 12 reiterating the same to a broader extent.

30 Akehurst, n. 2 above, 223-5. 
territory except by virtue of a permissive rule derived from international custom or from a convention. ${ }^{31}$

This has reinforced the understanding, expressed earlier on, that the exercise of the acts of sovereignty on the territory of another state is not the same as the exercise of jurisdiction in relation to acts that take place within that same state's territory. ${ }^{32}$

Once we conceptually and analytically separate the issue of jurisdiction as an entitlement to exercise sovereign authority in relation to a particular person or matter, from the issue of actually carrying out that sovereign authority within the territory of another state, the dilemma with the extra-territoriality of state jurisdiction becomes far less acute. Similarly, breaking out of the influence of the territoriality cliché, creating analytical difficulties for the operation of more than one extra-territorial category of jurisdiction, becomes far easier.

Conflicts of one state's jurisdiction with another state's territorial supremacy are no longer so inescapable either. For jurisdiction as such does not consist in exercising authority of the state abroad, nor securing obedience abroad to the same authority. It merely manifests the willingness of the state to exercise its own authority within its own sovereign realm, but in relation to certain acts and events that take place abroad.

Thus, territorial sovereignty is only one possible explanation for jurisdictional competence of states; it is also one that could lead to extreme results, as illustrated by the domestically developed perception that the UK Parliament, due to its sovereign legislative power, is subject to no territorial limits in terms of legislating and could take that power so far as to ban smoking in Paris or Vienna. The sovereignty-driven approach is therefore one that could provide some initial justification for the exercise of national jurisdiction, but also one that in practice requires a significant moderation, presumably by reference to validating and legitimating factors for jurisdiction other than the relevant state's sovereignty. Other reasons as to why the sovereignty-driven view is inconclusive, with its territoriality cliché, are that: (a) it does not provide enough allowance for the concurrence of competing jurisdictions; and (b) it does not give a clear and coherent view as to whether or why extra-territorial jurisdiction is permissible.

Another, complementary, explanation of state jurisdiction is the connection, link or nexus between the state and the relevant matter: the

\footnotetext{
31 Lotus, n. 26 above, 19.

32 E. Beckett, 'The Exercise of Criminal Jurisdiction over Foreigners' (1925) 6 BYIL 44.
} 
connection that international law sees as manifesting the legitimate interest of the relevant state to be involved with the relevant matter. The initial question this prompts relates not to the abstract reach of the state's sovereignty, but to the legitimate connection of the state with the matter underlying that jurisdictional action. Consequently, the distinction between territorial and extra-territorial jurisdictions should not be seen as preconceived, nor do they require different degrees of proof.

To illustrate, as Akehurst observes, 'customary international law permits a State to levy taxes only if there is genuine connection between the State and the taxpayer', ${ }^{33}$ not whenever the taxpayer is present or the relevant income is earned within the relevant state's domestic sovereign realm. Bowett concurs that, while the tax-related jurisdiction may appear to be based on the territorial principle, in reality it is not, because "the obligations imposed often bear on the person whilst abroad'. ${ }^{34}$

With the interest-driven conception of state jurisdiction, the principal question is whether the state has what is ordinarily termed as a "national interest' in the relevant matter (related to law-enforcement, economy or security); whether the assertion or non-assertion, exercise or non-exercise of a particular jurisdiction over the relevant person, event or affair makes that state better or worse off, causes benefit or burden, or brings advantage or disadvantage to it. These are issues only the state asserting jurisdiction could judge in the first place, as long as ultimate legal limits on the assertion of jurisdiction are observed.

Sir Eric Beckett admits that 'a state is the judge of what endangers its security or credit. It may choose to think that opium or gambling or atheistic literature is a menace to its safety, or speculation in its currency to its credit'. ${ }^{35}$ Mann further specifies that 'the legally relevant point of contact will have to be defined as indicating the State which has a close, rather than the closest, connection with the facts, a genuine link, a sufficiently strong interest'. ${ }^{36}$ And in this way jurisdiction comes across as a manifestation of public authority over something that can, one way or another, be said to be the business of the relevant state.

The legitimacy of state interest behind the assertion of state jurisdiction centres not on whether the state's law applies to the relevant matter in the first place, but whether international law allows, or eschews prohibiting, that state from making its own law applicable to that very same matter. In this sense, jurisdiction is not as free-standing an issue as

\footnotetext{
Akehurst, n. 2 above, 179.

Bowett, n. 11 above, 8-9.

Beckett, n. 32 above, 56.

Mann, n. 18 above, 46.
} 
it sometimes appears to be. The assertion of jurisdiction may merely be a tool for giving effect to rights and entitlements the state may have, depending on the context. Sometimes a state cannot do $\mathrm{X}$ in the first place, but can do the same $\mathrm{X}$ as a reciprocity measure in response to a preceding internationally wrongful act. That could be anything ranging from the denial of justice in relation to the state's own nationals abroad to the expropriation of property. In that case, and within the limit allowed by international law to countermeasures, ${ }^{37}$ jurisdiction could be asserted even if it otherwise would be wrongful under international law. Similarly, there are instances where the extra-territorial jurisdiction over particular foreign entities may be asserted in the context of economic boycott measures directed against the particular state. ${ }^{38}$ In this case, it will in the first place be the boycott the legality of which has to be assessed, not jurisdiction. If the boycott is lawful, in the sense of not violating a particular rule of international law, so would the jurisdiction be that sustains it; if not, then not.

\subsection{INITIAL ASSERTION AND ULTIMATE LEGALITY OF JURISDICTION}

The initial decision to establish or exercise jurisdiction is always a matter of domestic law. The ultimate criteria as to whether that jurisdiction is established or exercised lawfully, are inevitably international. Thus, what is initially a question of national law then falls to be judged as a matter of international law, very much in the same way as the International Court of Justice suggested, in the Nottebohm case, in relation to the conferral of nationality to the individual. ${ }^{39}$ An English court has similarly emphasized the need to ascertain 'To what extent can an English Court consistently with the general principles of international law that govern national jurisdictions exercise jurisdiction over the defendant domiciled abroad' ${ }^{40}$ This exercise could relate to the inherent characteristics in which jurisdiction is established or its particular applications, for instance, to distinguish between the assertion of jurisdiction through a statute and its application to particular facts.

37 See Articles 49 to 54 drafted by the ILC, Report of the International Law Commission on the Work of its Fifty-third Session (2001), Official Records of the General Assembly, Fifty-sixth Session, Supplement No. 10 (A/56/10).

38 See, on this, 1.10 .3 below.

39 Nottebohm (Liechtenstein v Guatemala) [1955] ICJ Reports 22.

40 Tallack $v$ Tallack [1927] P 211 at 219 (per Lord Merrivale). 
While the assertion of jurisdiction may convey the legal conviction of the relevant state that it is lawful under international law, this is not as such determinative of its lawfulness. Similarly, abstention from the exercise of jurisdiction does not inherently amount to a legal conviction of the abstaining state that such jurisdiction is not available under international law, as the Permanent Court of International Justice has clarified in Lotus. ${ }^{41}$ Nor are protests against the exercise of jurisdiction inevitably indications of illegality; protests assert illegality, they do not create or constitute it. A protesting state may be motivated by its own political and economic interests in the same way as the state asserting jurisdiction could be motivated. The legality of jurisdiction falls to be decided more on the basis of systemic considerations, such as the link or nexus factor, and the surrounding factor of concurrence. ${ }^{42}$

A state would, in principle, be liable for exercising its jurisdiction without the proper link to the matter, as well as for failing to establish or exercise jurisdiction as is, for instance, required by a treaty. As pointed out, 'an abuse or excess of jurisdiction over aliens is an infringement of the rights of their national states, against which, by virtue of the right which every state possesses to protect its citizens abroad, they are entitled to protest'. ${ }^{43}$

As Katzenbach suggests, in the area of the assertion and exercise of jurisdiction, 'each sovereign uses its power to effectuate what it conceives to be appropriate policy, and over a wide area there is agreement or, at least, tolerance'; the strongest case in this regard is presented by the ability to execute, and 'Legislative or judicial acts of state unaccompanied by an exercise of local power stand on a lesser footing in the international community'. ${ }^{44}$ The factual effectiveness of the exercise of jurisdiction is no doubt an important practical consideration. Obviously, the development of the content of much of the private international law-related exercise of jurisdiction has been determined by the control national courts realize that they have over the relevant matter: in the sense of the domicile or presence of litigants, control of relevant assets. But the factual control of such matters is a merely factual precondition of jurisdiction, not a basis for entitlement to exercise it. As Akehurst clarifies, 'ineffectiveness is not the same as illegality'. ${ }^{45}$

\footnotetext{
41 Lotus, n. 26 above.

42 On which latter element see 1.5 below.

43 Beckett, n. 32 above, 45.

44 Katzenbach, n. 27 above, 1131-3.

45 Akehurst, n. 2 above, 181.
} 
In the Arrest Warrant case (DRC v Belgium), President Guillaume asserted that the normal position in international law is that states can only exercise jurisdiction over a crime if, among other things, the accused is present in the territory of the state exercising jurisdiction. ${ }^{46}$ However, the existence of universal jurisdiction as jurisdictional title is an issue qualitatively different from that of the exercise of universal jurisdiction in absentia. State jurisdiction never derives from a fact, but only from a legal ground. Nor can the scope of jurisdiction be reduced or trimmed down solely on the basis that a certain factual precondition is not there.

\subsection{ESSENCE OF THE CONCURRENCE OF STATE JURISDICTIONS}

The essence of concurrence is that the same person or matter could, at one time, be validly considered by international law as falling within the jurisdiction of more than one state. For instance, a war crimes suspect could be under the territoriality jurisdiction of one, nationality jurisdiction of another, and universality jurisdiction of all other states. Legally speaking, the exercise of each of these jurisdictions would be just as lawful as that of others; the other jurisdictions would not be abolished, but merely pre-empted.

Jurisdiction is not a thing, object or hard matter to be owned on any absolute or exclusive terms, but an entitlement which, in the decentralized legal system, is always relative to the parallel entitlements of other states. According to Jennings, various headings of jurisdiction - nationality, objective territoriality or security - are relative in that they represent different aspects of legitimate state interests. ${ }^{47}$ The essence of the concurrence principle has been stated by the Permanent Court of Arbitration in the Deserters of Casablanca case, where the Tribunal stressed that 'the conflict of jurisdictions which has been mentioned cannot be decided by an absolute rule which would in a general manner accord the preference to either of the two concurrent jurisdictions'. ${ }^{48}$ The doctrine of concurrence also dictates that no state will be able to exercise

46 Arrest Warrant (DRC v Belgium) [2002] ICJ Reports 1, Separate Opinion, paras $16-17$.

47 Jennings, n 16 . above 152.

48 See Deserters of Casablanca (France v Germany), Award, (1909) 3 AJIL 755; see, for discussion, Jennings and Watts, Oppenheim, n. 18 above, 502-4. 
any exclusive jurisdiction over any matter unless so allocated under a particular conventional or customary rule of international law. ${ }^{49}$

The concurrence of jurisdictions is possible both under general international law and under particular treaty frameworks. Multilateral treaties can provide states with parallel jurisdiction under various headings. To illustrate, Article 5 of the Montreal Convention on Suppression of Unlawful Acts Against the Safety of Civil Aviation (1971), prescribes that states parties shall establish their jurisdiction over the relevant offences on various accounts of territoriality, nationality or presence within the state's territory.

The concurrence of two or more headings of jurisdiction exercisable in relation to the same person or subject matter means that, legally speaking, the basis of each of such jurisdictions is just as good as that of another. Akehurst takes an even more far-reaching view in favour of concurrence, in the sense that an individual may be subjected to jurisdiction under more than one national legal system, each of them requiring different kinds of conduct. But apart from extreme cases where one of those national laws are contrary to international law, which then would presumably be an issue of an internationally wrongful act relating to the content of legislation, rather than the legality of the jurisdictional heading through which that wrongful act is directed or perpetrated, Akehurst considers that there is no obvious way of resolving these conflicts of jurisdiction to legally prioritize one state's jurisdiction over that of another. ${ }^{50}$ As Lowe has pointed out in relation to jurisdiction over antitrust matters, 'if jurisdiction were in truth concurrent, then neither State, as a matter of law, could be denied the right to exercise it in good faith'. There is also no obvious acceptance in international law of certain jurisdictions being more paramount than others when they are purported to be exercised in relation to the same matter. ${ }^{51}$

If, however, the British view in the 1960s was that, in antitrust matters, the jurisdiction of states being generally concurrent, the territorial jurisdiction claim should generally prevail to the exclusion of other

49 Status of forces agreements regarding the presence of foreign armed forces on a state's territory provide the most conspicuous example of jurisdiction being allocated as between states as a way for one state to obtain absolute and exclusive jurisdiction over particular matters. On jurisdiction over foreign armed forces, see Aurel Sari, Chapter 11.

50 Akehurst, n. 2 above, 167-8; and further elaboration on this issue at 207-8.

51 Lowe, n. 12 above, 266. 
claims, ${ }^{52}$ then the view of this effectively taken was not of concurrent jurisdiction but of the priority jurisdiction available to one state, at times to the exclusion of another state's jurisdiction. The difficulty of this position would be that, while it accepts that the 'other' jurisdiction in principle exists and is lawful, the state's own jurisdiction should nonetheless be prioritized over it. It is hardly possible to find any intelligible support in state practice and opinio juris for such a complex, indeed cumbersome, position.

A conflict of jurisdictions does not inherently make any of conflicting jurisdictions illegal under international law. Instead, it is one of the essential implications of concurrence that national jurisdictions can and will be in mutual conflict from time to time.

\subsection{CIVIL AND CRIMINAL JURISDICTION}

It is common to speak of civil, criminal or administrative jurisdiction. The exercise of jurisdiction under most if not all of those headings is a matter of state choice, ${ }^{53}$ rather than being based on categorical distinctions strictly required by international law.

There may be some situational differences between civil and criminal jurisdiction, but they are empirical rather than prescriptive. It is true that, in public and criminal law, the determining factors are shaped by interests that states hold in enforcing their law and constitution in relation to extra-territorial events. However, the dilemma of territoriality of the foreign state versus that of the forum state arises both in criminal law and civil law, for in both these areas national courts may have to assert the competence of their own sovereign versus that of other sovereigns. As Katzenbach observes, the territoriality of criminal law has been adamantly recognized due to its public order nature. However, states assert their right to prosecute crimes committed by their nationals abroad. This and other exceptions have resulted in the matters being relativised, because just like states admit the foreign element in civil litigation for the sake of justice and fairness in private relations, so are they interested in prosecuting crimes committed abroad, now also for the sake of upholding their own legal system, values and safety. And 'obviously as in the case of conflicts doctrine, the key to territoriality lies in defining the connecting link'. ${ }^{54}$

\footnotetext{
52 Cf. ibid. 267.

53 Cf. Bowett, n. 11 above, 1.

54 Katzenbach, n. 27 above, 1139-43.
} 
Either on a sovereignty-driven or a link-driven view of jurisdiction, any across-the-board projection of an inherent distinction between civil and criminal jurisdiction is unwarranted, either in terms of asserting jurisdiction in the first place, or determining its ultimate reach. Both types of jurisdiction, criminal or civil, presuppose the same sovereign authority, and both require the state to have a proper connection with, or interest in, the relevant matter. To illustrate, as Akehurst observes, whether the object of UK legislation is crime or tort, it may be lawful or unlawful under international law regardless of the criminal/civil distinction. ${ }^{55}$ Overall, the legality of jurisdiction turns on the legitimacy of jurisdictional connection, regardless of the type of particular judicial proceedings, civil or criminal, through which jurisdiction is exercised.

In the United Kingdom, criminal jurisdiction is asserted mostly by statute. ${ }^{56}$ Civil jurisdiction could derive from the statute, but the assertion of civil jurisdiction also takes place in the context of private international law. The House of Lords confirmed in Atlantic Star that there is a:

general proposition that a foreign plaintiff, who can establish jurisdiction against a foreign defendant by any method recognised by English law, is entitled to pursue his action in the English courts if he genuinely thinks that that will be to his advantage and is not acting merely vexatiously. Neither the parties nor the subject matter of the action need have any connection with England. There may be proceedings on the same subject matter in a foreign court. It may be a far more appropriate forum. The defendant may have to suffer great expense and inconvenience in coming here. In the end the decisions of the English and foreign courts may conflict. But nevertheless the plaintiff has a right to obtain the decision of an English court. ${ }^{57}$

Then a careful description of the required balance follows in the House of Lords' judgment, in relation to a further issue of the stay of proceedings when national jurisdiction is purported to be used vexatiously, and the doctrine of forum non conveniens is accordingly discussed.

By claiming that its domestic conflict rule applies to a matter taking place abroad, the relevant state effectively claims jurisdiction over that very same matter in terms of public international law. According to Mann, English courts could assert jurisdiction if a contract is governed

\footnotetext{
55 Akehurst, n. 2 above, 189.

56 See 1.10.1 below.

57 Atlantic Star v Bona Spes [1974] AC 436 at 453 (per Lord Reid); see for a similar approach P. North and J. Fawcett, Cheshire and North's Private International Law (14th edn, 2008), pp. 353-4.
} 
by English law, even if there is no other domestic connection with the matter. ${ }^{58}$ Broadly speaking, private international law rules, such as those on property abroad, also relate to the concurrence of various national jurisdictions as a matter of public international law.

\subsection{PRESCRIPTIVE AND ENFORCEMENT JURISDICTION}

Both Bowett and Brownlie say that a state has enforcement jurisdiction only to the extent needed to enforce its legislative jurisdiction. ${ }^{59}$ But the question first to be asked is what test governs the legality of that legislative jurisdiction.

Mann suggests that 'The problem of enforcement jurisdiction arises when a State acts in foreign territory itself or at least takes measures which, though initiated in its own territory, are directed towards consummation, and require compliance, in the foreign State' ${ }^{60}$ The enforcement jurisdiction is generically a broad notion and can include various contexts right up to the state exercising physical force in the territory of another state to assert its rights, an extreme illustration of this being an extra-territorial abduction. ${ }^{61}$ Generally speaking, then, the issue of enforcement jurisdiction is, analytically as well as practically, broader than the basic rationale underlying jurisdictional entitlements of states: to exercise sovereign powers in relation to a particular person or matter. In other words, the enforcement jurisdiction relates to the range of means the state can employ to give effect to jurisdiction that it is asserting on another, discrete, substantive ground, whether territorial or extraterritorial.

For instance, either the arrest of an individual within the state's own territory, or the abduction of an individual from the territory of a foreign state, could be an exercise of a kind of 'enforcement jurisdiction' while giving effect to the mainstream jurisdiction that the abducting state is lawfully or unlawfully asserting over that very same individual on the

58 Mann, n. 17 above, 79.

59 I. Brownlie, Principles of Public International Law (2008), p. 311; Bowett, n. 11 above, 1.

60 Mann, n. 18 above, 128.

61 Ibid. 129; see also F.A. Mann, 'Reflection on the Prosecution of Persons Abducted in Breach of International Law' in Y. Dinstein and M. Tabory (eds), International Law at a Time of Perplexity: Essays in Honour of Shabtai Rosenne (Dordrecht, 1989), p. 407. 
basis of territoriality, extra-territoriality or even universality. Even despite the existence of that mainstream jurisdiction, states may have to decline its exercise because the custody over the relevant individual has been obtained through unlawful means. ${ }^{62}$

But this is not really an issue of a jurisdictional title, but of the consequent action that either respects or violates another state's sovereignty and territorial supremacy. Jurisdiction per se, whether 'prescriptive' or 'enforcement', is about whether, under international law, the state can act in relation to the relevant matter in the sense that there is a proper link between that state and that matter. The actual carrying out of this, whether by prescribing or by enforcing, obviously has to take place within that state's territory.

The issues arising and relevant across the above divide include matters relating to mutual legal assistance, provision of documents to assist litigation and extradition of suspects, as well as those relating to the reach and reciprocal recognition of judgments. ${ }^{63}$ These matters are implications of the fact that, as Bowett observes, in certain cases the state may have prescriptive jurisdiction but not enforcement jurisdiction, because the accused over which the state establishes prescriptive jurisdiction may be outside its territory. ${ }^{64}$

These are the issues consequential upon the exercise of jurisdiction, but they do not inherently determine or preclude the lawfulness of the very existence or exercise of jurisdiction. Whether jurisdiction is exercised depends on the proper jurisdictional link. It is another issue whether the exercise of such jurisdiction is being assisted as a matter of national discretion to assist a lawful exercise of jurisdiction by another state, or opposed through the reaction to an internationally wrongful act which the excessive exercise of foreign jurisdiction may involve.

62 See the decision of the House of Lords in $R v$ Horseferry Road Court, Ex p. Bennett [1994] 1 AC 42; and the European Court of Human Rights in Stocke $v$ Germany, ECHR Series A, No. 199; the only exception from this pattern relates to those who are being tried for the commission of core international crimes, see Attorney-General of the Government of Israel v Adolf Eichmann [1961] 36 ILR 5.

63 See on this, Akehurst, n. 2 above, 210 at $232 \mathrm{ff}$.

64 Bowett, n. 11 above, 1. 


\subsection{MERIT AND CONTINUING RELEVANCE OF LOTUS}

The Permanent Court of International Justice in Lotus was dealing with the collision between French and Turkish vessels at sea, as a consequence of which the French officer was tried in Turkey. The challenge this situation presented to the Court was to rationalize jurisdictional principles not only in terms of their mainstream area of application but also, as it were, at their margins.

The Court had to address the ground that had already been debated in a substantial manner. A year before the Court handed down the Lotus judgment, Sir Eric Beckett wrote that:

a rule or an exception to a rule of international law can only be made by the general consent of all members of the family of nations, and in such an apparent conflict of opinion the vital question is 'On whom is the burden of the proof? Who must show that the general consent of nations is on his side, he who asserts jurisdiction over aliens or he who denies it?' Framed in this way there seems to be only one possible answer: 'He who claims jurisdiction'. The opposite answer would involve the proposition, that ... there was no limit by international law to a state's jurisdiction over aliens. ${ }^{65}$

Jennings, on the other hand, suggests in a later commentary that 'to ask on whom the burden of proof is to fall is little more than a way of begging the principal question'.66 Straightforward as it was, Sir Eric Beckett's proposition was not taken up by the Permanent Court of International Justice. The PCIJ drew a key distinction between the exercise of jurisdiction in relation to a particular place and the exercise of sovereign authority within the same place. The Court held that:

It is certainly true that ... vessels on the high seas are subject to no authority except that of the State whose flag they fly. In virtue of the principle of the freedom of the seas, that is to say, the absence of any territorial sovereignty upon the high seas, no State may exercise any kind of jurisdiction over foreign vessels upon them. Thus, if a war vessel, happening to be at the spot where a collision occurs between a vessel flying its flag and a foreign vessel, were to send on board the latter an officer to make investigations or to take evidence, such an act would undoubtedly be contrary to international law. But

65 Beckett, n. 32 above, 50; per contra Akehurst, n. 2 above, 167.

66 Jennings, n. 16 above, 152. 
it by no means follows that a State can never in its own territory exercise jurisdiction over acts which have occurred on board a foreign ship on the high seas. ${ }^{67}$

According to the Court, "This conclusion could only be overcome if it were shown that there was a rule of customary international law which, going further than the principle stated above, established the exclusive jurisdiction of the State whose flag was flown', and 'the existence of such a rule has not been conclusively proved'.68 This was also due to broader considerations related to the system of international law, because:

Far from laying down a general prohibition to the effect that States may not extend the application of their laws and the jurisdiction of their courts to persons, property and acts outside their territory, [international law as it stands at present] leaves them in this respect a wide measure of discretion which is only limited in certain cases by prohibitive rules; as regards other cases, every State remains free to adopt the principles which it regards as best and most suitable. ${ }^{69}$

The dissent by Lord Finlay required positive proof of the rule authorizing Turkey to exercise jurisdiction in such situation. ${ }^{70}$ Later on, Article 11(1) of the 1958 Geneva Convention on the High Seas adopted a position different from Lotus, ${ }^{71}$ but this provision merely constitutes a lex specialis against the background of the Lotus principle applying as part of the general law. More recently, in $R v G u l$, the UK Supreme Court adopted the approach that follows Lotus. ${ }^{72}$

In pragmatic terms, the principle stated in Lotus is useful as an organizing principle, because state practice often may be divided, unrepresentative or neutral, and thus be unable to provide a definite answer. This became clear when the issue of universal jurisdiction over core international crimes was discussed in the Joint Separate Opinion in the Arrest Warrant case:

\footnotetext{
67 Lotus, n. 26 above, 25.

68 Ibid. 25-6.

69 Ibid. 18-19.

70 Ibid., Dissenting Opinion, 52.

71 Article 11 provides that, 'In the event of a collision or of any other incident of navigation concerning a ship on the high seas, involving the penal or disciplinary responsibility of the master or of any other person in the service of the ship, no penal or disciplinary proceedings may be instituted against such persons except before the judicial or administrative authorities either of the flag State or of the State of which such person is a national'.

72. $R$ v Gul [2013] UKSC 64.
} 
none of the national case law to which we have referred happens to be based on the exercise of a universal jurisdiction properly so called, there is equally nothing in this case law which evidences an opinio juris on the illegality of such a jurisdiction. In short, national legislation and case law - that is, State practice - is neutral as to exercise of universal jurisdiction. ${ }^{73}$

This demonstrated the utility of having an organizing principle, when state practice cannot provide a definitive answer in terms of resolving conflicting presumptions. Moreover, the adoption of an approach contrary to the one set out in Lotus would lead to an extreme, and counter-factual, outcome that certain kinds of nationality jurisdiction, of the kind that France may have claimed in that case, are absolute and exclusive of the conflicting and concurrent jurisdictions of other states.

\subsection{PARTICULAR HEADINGS OF JURISDICTION: TERRITORIALITY, NATIONALITY AND EXTRA-TERRITORIALITY}

Being exercised under a particular (well-recognized and generally accepted) heading neither privileges the relevant jurisdiction, nor renders it dubious. However sound and obvious the particular jurisdictional heading may be, there is, more often than not, the possibility of the same matter concurrently falling within the jurisdiction of another state. Therefore, particular headings of jurisdiction should be viewed merely as analytical rationalizations of the genuine link between the state that asserts jurisdiction and the relevant person, matter or incident, not as by itself determinative of jurisdictional entitlements.

Many authors would agree that territorial jurisdiction is the most fundamental, obvious and undisputed instance of the state exercising its jurisdiction, because regulating state affairs within its territory is axiomatic. However, according to Bowett, the territoriality basis is used flexibly by states to support jurisdiction to protect the states' interests in resources located outside the territory of the state yet conceded under international law to be within the control of that state. ${ }^{74}$

The nationality jurisdiction is also among the obvious jurisdictional headings. It relates to prosecuting a state's national or a person who commits a crime against that national. On the other hand, the assertion of

73 Arrest Warrant, n. 46 above, para. 45; and see para. 54 for reference to Lotus, in relation to the exercise of universal jurisdiction in absentia.

74 Bowett, n. 11 above, 4-5. 
jurisdiction over an individual due to the nationality link could prove just as controversial in practice, as could be the case with some other headings of extra-territorial jurisdiction. Accordingly, as Bowett suggested, 'the link of nationality may become no more than prima-facie evidence that the person's conduct is properly the concern of the State of nationality'. ${ }^{75}$ The nationality link could indeed be used as a premise for politically motivated persecution of individuals.

Another aspect of the relevance of nationality jurisdiction could arise when the state's national is murdered or injured abroad. But even in such cases of obvious connection between the state and the crime (or indeed tort), controversies would not go away. The extra-territorial assertion of the nationality jurisdiction could be seen as politically controversial, aimed at frustrating the territorial jurisdiction of the state on whose territory the relevant incident has taken place. Whether that would be so would depend on the specific incidences of the particular case. Similarly, as Mcgarthy has demonstrated, the passive personality principle applicable, for instance, in the case of terrorist offences or used in some cases to protect the state's nationals present abroad, could cause political controversies and provoke claims of interference in another state's domestic affairs. ${ }^{76}$

The room for a conflict of interests is often there, anyway. To illustrate: the state of emigration may have an interest to cover departing nationals while the state of arrival has an interest to cover new domiciliaries. ${ }^{77}$ Akehurst suggests an even broader position: that public international law would not prohibit states to apply the lex fori to determine the status of all individuals, whether or not having a connection to the relevant state. ${ }^{78} \mathrm{~A}$ state may clash with a foreign state even if they try a foreign national on the basis of the crime committed within the forum's territory. Consequently, there is always some potential for aggravation and irritation in mutual relations of states, including in cases of the lawful assertion of state jurisdiction under its most mainstream and generally recognized headings.

It has been suggested that "The Law of Nations does not recognize the assumption of jurisdiction for "protection"; there never has been any such general consent by the nations as would be required to make this doctrine

\section{Ibid. 8.}

76 And this has led some states to require executive consent before such jurisdiction is exercised. J.G. Mcgarthy, 'The Passive Personality Principle and Its Use in Combatting International Terrorism' (1989) 13 Fordham JIL 325.

77 Akehurst, n. 2 above, 221.

78 Ibid. 230. 
a part of international law'. ${ }^{79}$ On the other hand, Bowett suggests that there is no doubt of the validity of the protective principle, especially when a conduct that constitutes a crime is one that threatens the state's security. The protective principle justifies the criminalization, with extraterritorial effect, of espionage, sedition, counterfeiting of currency or attack against embassies or consulates abroad. Furthermore, 'there is little doubt, in this day and age, that a State's security is economic as well as political, so that the conduct posing a real threat to a State's economy could be subjected to the State's jurisdiction' ${ }^{80}$

\subsection{EXTRA-TERRITORIAL JURISDICTION}

\subsubsection{Criminal Jurisdiction of English Courts}

In English criminal law, the process of criminalization, defining the ambit of particular crimes, also involves the assertion of territorial or extraterritorial jurisdiction. The initial approach has been, as the Macleod case suggested, that 'all crime is local' and criminal jurisdiction over it belongs to the territorial state. ${ }^{81}$ However, as Sir Robert Jennings observed, the notion that all crime is local has never commanded a general assent of states and thus become part of international law. ${ }^{82}$ It was stated in the early case of Zollverein that 'The laws of Great Britain affect her own subjects everywhere - foreigners only when within her own jurisdiction'. ${ }^{83}$ As Lord Morris then observed in Treacy, 'the general principle of the common law of England is that the exercise of criminal jurisdiction does not extend to cover acts committed on land abroad' ${ }^{84}$

A somewhat open-ended approach by Lord Morris in Treacy suggests that:

Unless, therefore, there is some provision pointing to a different conclusion, a statute which makes some act (or omission) an offence will relate to some act (or omission) in the United Kingdom. Even where a statute creating a criminal offence is clearly expressed so as to cover acts committed outside the

\footnotetext{
79 Lotus, n. 26 above, Dissenting Opinion of Lord Finlay, 56.

80 Bowett, n. 11 above, 10-11.

81 Macleod [1891] AC 455 at 458-9.

82 Jennings, n. 16 above, 149.

83 Zollverein, (1856) 166 ER 1038 at 1040.

84 Treacy $v$ DPP [1971] AC 537 at 552 (per Lord Morris).
} 
jurisdiction, it will, in the absence of further clear provision only be regarded as covering such acts when committed by British subjects. ${ }^{85}$

\section{However:}

It would be open to Parliament to enact that if a British subject committed anywhere an act designated as blackmail he would commit an offence punishable in England. Such an enactment would, however, have to be in clear and express terms: specific provision would have to be made with regard to acts committed abroad. ${ }^{86}$

Thus, the notions of territoriality and extra-territoriality become relative even in cases where the criminalization is deemed to be primary territorial. Courts have some flexibility in construing jurisdiction by identifying where the crime has been committed either in terms of locus, ${ }^{87}$ or of the relationship between the perpetrator and aider or abettor. Then, in $R v$ Oliphant, also a more principled justification in favour of extra-territoriality of jurisdiction was offered by Lord Alverstone, dealing with the "well-recognised rule of the criminal law that where an offence has been wholly committed abroad it cannot be tried in England' and with the argument that 'an act committed out of the jurisdiction, but having an effect within the jurisdiction, is triable in the place where it has that effect'.

According to Lord Diplock:

It would be an unjustifiable interference with the sovereignty of other nations over the conduct of persons in their own territories if we were to punish persons for conduct which did not take place in the United Kingdom and had no harmful consequences there. But I see no reason in comity for requiring any wider limitation than that upon the exercise by Parliament of its legislative power in the field of criminal law. 88

Lord Diplock further emphasized that:

where the definition of any such offence contains a requirement that the described conduct of the accused should be followed by described consequences the implied exclusion is limited to cases where neither the conduct nor its harmful consequences took place in England or Wales. ${ }^{89}$

\footnotetext{
85 Ibid. 553.

86 Ibid. 552 (per Lord Morris).

$87 R$ v Oliphant [1905] $2 \mathrm{~KB} 67$ at 72-3.

88 Treacy, n. 84 above, 561.

89 Ibid. 564 (emphasis in original).
} 
The separate reference to harmful consequences of the act, in addition to its perpetration, provides a boost for the extra-territorial jurisdiction on terms comparable to the effects doctrine.

The case of Joyce, ${ }^{90}$ dealing with the pro-Nazi propaganda conducted from abroad by a person who had fraudulently acquired British citizenship, may be rather specific to be generalized in terms of jurisdictional reach of the English legal system. The reference there was made to the United Kingdom's continuing personal supremacy over Joyce while abroad, ${ }^{91}$ and thus to the latter's continuing allegiance, even though his nationality in the first place had never been a straightforward matter. The real and major question is not whether Joyce could be prosecuted in England, but whether one could be prosecuted in England for the similar activities producing effect within the jurisdiction even if one has no nationality or comparable connection with the forum. To answer this question negatively would be to emasculate the forum's jurisdiction and render it impotent in dealing with precisely these kinds of dangerous activities. If you catch one and let ten others get away with it, solely because they are not the forum state's nationals, the whole rationale of criminalization becomes ethically dubious and practically ineffective. After all it was broadcasting, not nationality, that provided the initial and continuing rationale for prosecuting Joyce. Whoever's national Joyce was, the crime was inherently extra-territorial both in its design and effect, and in the longer run it may be counter-productive to pretend otherwise.

More recently, the purposive construction of a statute to secure its extra-territorial reach was adopted by the English Court of Appeal in Hundal, dealing with the counter-terrorist context:

The question that arises is: does the fact that the activities and their involvement in the [relevant proscribed] organisation took place in Germany, where it was not proscribed, mean that they could not be guilty of the offence? If the position was that because an organisation carries on its activities in more than one country this meant that by joining the organisation in a country which is outside the jurisdiction of these courts, then the Terrorism Act would not apply to that organisation, this would enable a coach and horses to be driven through the objects of the legislation. ${ }^{92}$

Therefore, it looks rather odd that in the next paragraph of the judgment, the Court professes to disclaim the extra-territoriality of section 11(1) of

\footnotetext{
$90 \quad$ DPP v Joyce [1946] AC 347.

91 Ibid. 376 (per Lord Porter).

92 Hundal [2004] EWCA Crim 389, paras 11-12.
} 
the Terrorism Act $2000 .{ }^{93}$ This looks like an attempt to square the circle. Even if the person would be prosecutable once on the British soil, they still would be prosecutable for what they did outside the United Kingdom. Under the 2000 Act, being physically in the United Kingdom is not an offence; being a member of the proscribed organization is.

The Terrorism Act 2006 subscribed to an even more far-reaching approach to extra-territoriality. ${ }^{94}$ According to section $17(1)$ :

If (a) a person does anything outside the United Kingdom, and (b) his action, if done in a part of the United Kingdom, would constitute an offence falling within subsection (2), he shall be guilty in that part of the United Kingdom of the offence.

Such broad assertion of extra-territorial jurisdiction could hardly be rationalized if we adhere to the sovereignty-driven approach to jurisdiction, which approach would then result in a rather substantial presumption to be applied against the entitlement of the state to regulate extra-territorial matters in such a far-reaching manner. However, the United Kingdom's assertion of the extra-territorial jurisdiction would become more clearly understandable if we see it through the prism of the interest-driven approach to jurisdiction. This approach would enable us to rationalize this extra-territorial jurisdiction by reference to the interest of combatting terrorist activities which has motivated the UK Parliament to adopt such a statutory position on jurisdiction.

93 The Court suggests that 'properly understood, the provisions of section 11 do not have extra-territorial effect. Properly understood, what is required is for there to be someone who is in this country, and therefore subject to its jurisdiction (as both the appellants were), who at the time that he is in this country is a member of the proscribed organisation. In order to establish that the person concerned is a member of the proscribed organisation, evidence can be given that the person joined the organisation from abroad or when abroad. That would not in itself make that person guilty of an offence. He would only be guilty of an offence when he was in this country. Either he would have to travel to this country in order to commit an offence after he became a member or he would already have had to be in this country and joined the local foreign branch of the proscribed organisation while in this country. But in any event the criminal law would apply to his activities because of his presence in this jurisdiction: his coming here as a member or his being a member in this country of the proscribed organisation', para. 13.

94 As discussed in Rangzieb Ahmed and Habib Ahmed $v R$ [2011] EWCA Crim 184, CA (Crim. Div.), 25 February 2011, para. 96 ff. 


\title{
1.10.2 Effects Doctrine in the Jurisprudence of US and English Courts
}

Lowenfeld defines the effects-based jurisdiction as the "jurisdiction to prescribe, on the basis of effects caused by the challenged activity in [the state's] territory, even when no part of the activity was carried out in its territory'; the effects must be 'direct, substantial, and foreseeable'. ${ }^{95}$ Some, though insufficient, understanding of the extra-territorial effects doctrine was manifested in the early twentieth century. As Sir Eric Beckett observed by reference to a previous commentator:

\begin{abstract}
Wharton, an American writer, said in 1885, 'There is no civilized state that has not passed statutes making it a criminal offence for foreigners even in their own countries to forge its securities' - a statement which, though inaccurate, is strong evidence of his view of the legality of the jurisdiction claimed ... Conspiracies against the life of the head of the state, revolutions fomented against the constitution, the circulation of forged currency notes through the post, are simple instances, not open to dispute. ${ }^{96}$
\end{abstract}

From here, one possibility would be to adopt a pedantic approach and require the existence of a positive rule of international law to validate the assertion and exercise of jurisdiction, in addition to the above example as to securities forgery, in relation to all other extra-territorial economic activities, whether currency forgery, antitrust or other economic threats. A more straightforward and down-to-earth approach would, however, be one that suggests that the widespread acceptance of the extra-territorial jurisdiction in relation to securities forgery is merely an implication of states admitting the legality of extra-territorial jurisdiction, whenever the proper link between the forum state and the matter covered by the relevant exercise of jurisdiction can be demonstrated.

According to Akehurst, whether the state will establish a civil or criminal jurisdiction over antitrust matters is its domestic legal choice, and the limits on civil and criminal jurisdiction in this case are the same. ${ }^{97}$ Akehurst further suggests that a 'constituent element' of the act need not necessarily have occurred within the forum state's territory and that this applies both to civil and criminal jurisdiction. ${ }^{98}$ The US Supreme

95 A. Lowenfeld, 'Jurisdictional Issues Before National Courts: The Insurance Antitrust Case' in K. Meessen (ed.), Extraterritorial Jurisdiction in Theory and Practice (London: Kluwer, 1996), p. 6.

96 Beckett, n. 32 above, 56.

97 Akehurst, n. 2 above, 191-2.

98 Ibid. 195-6. 
Court decision in Alcoa sought to frame the effects doctrine in terms of the territoriality principle, referring to conduct outside the United States' borders 'that has consequences within its borders'. ${ }^{99}$ Also, it was observed that:

we are concerned only with whether Congress chose to attach liability to the conduct outside the United States of persons not in allegiance to it ... Nevertheless, it is quite true that we are not to read general words, such as those in this Act, without regard to the limitations customarily observed by nations upon the exercise of their powers; limitations which generally correspond to those fixed by the 'Conflict of Laws'. ${ }^{100}$

The Court in Alcoa accepted the general interpretative relevance of international law and comity, yet adhered to a broader understanding of the effects jurisdiction.

A similarly expansive understanding of extra-territorial jurisdiction was upheld in United States v ICI. It was held not to be unlawful or an intrusion into a foreign sovereign's authority to direct a foreign company 'to remove the harmful effects on the trade of the United States'. ${ }^{101}$ Later on, US courts began to introduce the balancing of interests test to further rationalize the nexus requirement with the relevant matter. To some extent, this amounted to a moderation. The Court of Appeals for the Ninth Circuit in Timberlane suggested:

That American law covers some conduct beyond this nation's borders does not mean that it embraces all, however. Extraterritorial application is understandably a matter of concern for the other countries involved. Those nations have sometimes resented and protested, as excessive intrusions into their own spheres, broad assertions of authority by American courts ... it is evident that at some point the interests of the United States are too weak and the foreign harmony incentive for restraint too strong to justify an extraterritorial assertion of jurisdiction.

It was further suggested that 'The effects test by itself is incomplete because it fails to consider other nations' interests' ${ }^{102}$ Not that the effects jurisdiction was unlawful; it was merely an initial criterion, to be complemented, as a matter of national judicial choice, by the balancing test to see how strong the relevant American interest was in comparison with other nations' interests to justify effect-based jurisdiction.

\footnotetext{
99 United States v Aluminium Company of America, 4 F.Supp. 97 (1941).

100 United States v Alcoa, 148 F.2d 416, 443 (1944).

101 United States v ICI, 105 F.Supp. 215 (1952).

102 Timberlane Lumber Co. v Bank of America, Ninth Circuit, 611-12 (1976).
} 
The US court in Laker Airways $v$ Sabena supported an even broader understanding of the effects jurisdiction, characterized as the 'territorial effects doctrine'. The court's approach was that:

Even if invisible, the radiating consequences of anti-competitive activities cause economic injuries no less tangible than the harmful effects of assassins' bullets or thieves' telephonic impulses. Thus, legislation to protect domestic economic interests can legitimately reach conduct occurring outside the legislating territory intended to damage the protected interests within the territory. As long as the territorial effects are not so inconsequential as to exceed the bounds of reasonableness imposed by international law, prescriptive jurisdiction is legitimately exercised. ${ }^{103}$

If this reasoning is followed it seems that, on balance, the approaches of territoriality and of effects are not so much separate rules as interpretative rationalizations of the overall substantive connection test. Effects produced, from abroad, within the forum's territory can and do amount to such substantive connection. The court's approach was not dissimilar to the English court's above-mentioned references to extra-territoriality when 'harmful consequences' within the forum's territory could materialize from an act initially perpetrated abroad.

The Sabena case also conceived the entire matter within the framework of concurrence of jurisdictions as between courts of different states, observing that 'the parallel proceeding rule counsels against interference with a foreign court's exercise of concurrent jurisdiction' ${ }^{104}$ The court also articulated the reasons dictating that the effects doctrine can ultimately be more flexible, and less intrusive into foreign legal systems, than the nationality-based jurisdiction, for 'besides ignoring important domestic interests, the paramount nationality rule would generate more interference than it would resolve. Legislation based on nationality tends to encourage chauvinism and discrimination without enhancing international comity', 105 while the effects doctrine, at least in its American version, allows for a flexible balancing of interests. The overall premise for the US courts' jurisdiction was that 'No foreign court can supersede the right and obligation of the United States courts to decide whether Congress has created a remedy for those injured by trade practices adversely affecting United States interests'; and then, in the spirit reflecting the concurrence of the two jurisdictions, it was added that:

103 Laker Airways v Sabena, 731 F.2d 909 (1984), at para. 43; and case review by M. Leigh in (1984) 78 AJIL 666.

104 Sabena, n. 103 above, para. 72.

105 Ibid. para. 103. 
Under the nationality base of jurisdiction, Britain can punish its corporations for walking through that courthouse door, but it cannot close the American door. Thus, although British courts can sanction their citizens for resorting to United States antitrust remedies, United States courts are not required to cut off the availability of the remedy. ${ }^{106}$

It seems, overall, that the US-style effects doctrine is not generically different from the versions of extra-territorial jurisdiction other states have used. After the evolving position in the US case law, Lowenfeld has concluded that 'it is now clear beyond doubt that the Supreme Court majority and minority - understands that the reach of a nation's law is a subject of international law - public customary international law' ${ }^{107}$

The interest-balancing exercise, as presumably required by comity, should be seen not as the mirror-image of the juridical lawfulness of the underlying exercise of the effects-based jurisdiction, but as one of the ways of making allowance for the options and possibilities that the concurrence framework as applicable to otherwise lawful exercises of extra-territorial jurisdiction allows the relevant states to take advantage of. The US courts' reliance on the reasonableness requirement as part of comity, and their consequently making that allowance for other nations' interests is, in essence, the unilateral moderation by US courts of the legality allowance available to this state under international law, instead of pressing the freedom available under that allowance to its extreme limits.

An early British reaction to the US antitrust jurisdiction came with the case of British Nylon Spinners v ICI, ${ }^{108}$ where Lord Evershed MR responded to the US Court's position in the ICI case (above). The conceptual basis underlying Lord Evershed's approach was that:

the right [involved in the case] may be described as their right under the contract, being an English contract made between English nationals and to be performed in England ... That is a right ... which is English in character and is subject to the jurisdiction of the English courts; and it seems to me that the plaintiffs have at least established a prima facie case for saying that it is not competent for the courts of the United States or of any other country to interfere with those rights or to make orders, observance of which by our courts would require that our courts should not exercise the jurisdiction which they have and which it is their duty to exercise in regard to those rights. ${ }^{109}$

\footnotetext{
106 Ibid. para. 101.

107 Lowenfeld, n. 95 above, 6 (emphasis in original).

108 British Nylon Spinners v ICI [1953] 1 Ch. 19.

109 Ibid. 26.
} 
Lord Evershed further disagreed with the position of the US judge that it was not an intrusion on the authority of a foreign sovereign to make directions addressed to that foreign sovereign or to its courts or to nationals of that foreign Power effective to remove (as he said) "harmful effects on the trade" of the United States'. ${ }^{110}$ Denning LJ was equally clear that 'The writ of the United States does not run in this country, and, if due regard is had to the comity of nations, it will not seek to run here'. ${ }^{111}$

It was precisely this reasoning that, on balance, leads to the conclusion that the jurisdictional attitude of the Court of Appeal has contradicted the thesis of the concurrence of British and US jurisdictions. The above observations demonstrate that the Court of Appeal opposed the very competence of US courts to exercise jurisdiction, even if it was clear that the relevant transactions had produced harmful effects within the United States, if the matter was in the first place governed by English law and litigated between British subjects.

Initially at least, then, what British Nylon Spinners contextually proves is that each forum is responsible for protecting its own trade and legal system and that, in the absence of some supra-national authority to distribute jurisdiction, British and US forums remain concurrently competent on the matter, each of them retaining their right not to give effect to another's prescriptions. It also bears repeating that the national assertion of jurisdiction takes place against the background of both Lotus and the concurrent nature of nearly all the jurisdiction that is available to states. The assertion of jurisdiction by one state does not inherently negate that of another state, but merely pre-empts its exercise.

As a matter of fact, English courts have encountered the situation where the exercise of foreign (US antitrust) jurisdiction was controversial, and was opposed by the executive branch of the British government, ${ }^{112}$ partly on the grounds of its alleged unlawfulness, and Parliament had intervened through the adoption of the Protection of Trading Interests Act 1980. In British Airways Board v Laker, the issue was whether English courts could enjoin Laker from litigating its case against the British Airways before US courts. ${ }^{113}$ The 1980 Act was raised in Laker, but without giving to the Act the inherent effect of offsetting US courts' jurisdiction to order threefold damages. English courts instead appear to

\footnotetext{
110 Ibid. 25.

111 Ibid. 28.

112 Lowe, n. 12 above, 257 at 267-72.

113 BA Board v Laker [1985] AC 58.
} 
have located the matter, however controversial, within the context of the concurrence of British and US jurisdictions.

Similarly, it was asserted earlier before the House of Lords in Westinghouse that 'The assertion of extraterritorial jurisdiction in antitrust matters represents an extension of the economic policy of one state which is likely to conflict with that of other states', and that the outcome that entailed was 'undesirable' for the business environment. ${ }^{114}$ The relativity of this matter was then witnessed in Lord Wilberforce's observation that 'It is axiomatic that in anti-trust matters the policy of one state may be to defend what it is the policy of another state to attack'. ${ }^{115}$ If so, then it is not really about considering the 'other' jurisdiction as inherently unlawful, but merely denying domestic effect to certain of its implications.

As a matter of international law, in antitrust cases containing foreign elements, concurrent jurisdiction is the rule rather than the exception. The interest balancing rule and the reasonableness requirement as such cannot be seen to be part of international law, because such an approach would aim (implausibly) at demonstrating the reasonableness of the action in a way acceptable to all states holding many different views. ${ }^{116}$

English courts have broadly subscribed to this approach. The High Court judgment in Laker disapproved:

any submission that an antitrust action based in part, or even substantially, on acts committed outside the United States by English companies carrying on business in the United States in relation to the carrying on of that business constitutes such an invasion of sovereignty that a United Kingdom company engaged in a like business should be restrained from pursuing its claim ... It is equally clear that invasion of sovereignty or extra-territoriality afford no ground. They too have been dealt with by Parliament, to some extent directly and to some extent by giving to the Secretary of State wide powers to act in case of need. The direct parliamentary intervention does not avail [the airlines]. The powers conferred by Parliament have not been exercised and a United Kingdom designated airline carrying on business in the United States by permission of the United States Government must prima facie comply with United States law or take the consequences. ${ }^{117}$

114 Westinghouse Electric Co. [1978] AC 547 at 594; although it was also said that this jurisdiction was not in accordance with international law, ibid. 631 (per Viscount Dilhorne).

115 Westinghouse, n. 114 above, 617.

116 K.M. Meessen, 'Antitrust Jurisdiction under Customary International Law' (1984) 78 AJIL 783 at 801-2.

117 BA Board v Laker [1984] QB 142 at 163-4 (per Parker J). 
In the House of Lords in the Laker case, as Lord Diplock stated, their Lordships were:

confronted in the civil actions with a case in which there is a single forum only that is of competent jurisdiction to determine the merits of the claim; and the single forum is a foreign court. For an English court to enjoin the claimant from having access to that foreign court is, in effect, to take upon itself a one-sided jurisdiction to determine the claim upon the merits against the claimant but also to prevent its being decided upon the merits in his favour. This poses a novel problem, different in kind from that involved where there are alternative fora in which a particular civil claim can be pursued: an English court and a court of some foreign country both of which are recognised under English rules of conflict of laws as having jurisdiction to entertain proceedings against a defendant for a remedy for acts or omissions which constitute an actionable wrong under the substantive law of both England and that foreign country. ${ }^{118}$

In Westinghouse, where the House of Lords has ruled that British authorities were not obliged to accede to the American letter rogatory addressed to the High Court, the terms of an international treaty, namely, the 1980 Convention on Taking Evidence Abroad, led English courts not to assist the exercise of US extra-territorial jurisdiction; but not to hold that anything determined in that jurisdiction was to be seen as inherently unlawful. In Laker, courts were asked to go much further than in Westinghouse, for in Laker a similar result offsetting the effect of the US extra-territorial jurisdiction was not necessarily obtainable on the basis of an international treaty. The difference between Westinghouse and Laker also was that, in the former case, English courts were requested to take positive action to assist the exercise of US extra-territorial jurisdiction; while in the latter case they were requested to issue injunctions against Laker not to take part in the US proceedings based on that jurisdiction. In neither case did they accede to the request. The overall conclusions in both cases did, by and large, avoid the legal condemnation of the US jurisdiction as such.

Thus, overall, the antitrust litigation saga before English courts did not amount to state practice that would adversely affect the legality of the US extra-territorial jurisdiction over non-nationals (and, given that in the English legal system law is what courts say it is, the position of the judiciary should be seen to carry greater weight). This litigation thus did

118 Laker, n. 113 above, 80 (emphasis in original); Lord Diplock also agreed with Parker J of the High Court 'who held that it did not assist [the airlines] in their claims to injunctions', ibid. 85. 
not inherently commit the United Kingdom against the extra-territorial jurisdiction in any manner. Even Lord Donaldson MR, who granted injunctions in the Court of Appeal in Laker (later on to be lifted by the House of Lords), ${ }^{119}$ did not contradict the thesis that US courts did have the antitrust jurisdiction that they asserted pursuant to the US legislation. ${ }^{120}$ It is therefore right to suggest, in relation to the British position regarding the US antitrust jurisdiction, that the view that:

if jurisdiction were concurrent ... the territorial claim should generally prevail to the exclusion of claims on other bases ... is difficult to reconcile with the concept of concurrence, and it may be that no more than a principle of comity was being advanced here ... rather than law. ${ }^{121}$

Another remark on what English courts have actually done is also pertinent:

For a domestic court to take the position that considerations of relative national interests are irrelevant to the question whether legitimate authority to prescribe or enforce exists reinforces a perception that the court operates outside the international law formation process and should view itself as playing principally a political role in determining whether or not effective power should be exercised. ${ }^{122}$

This is accurate with one caveat: courts did not play a political role. They merely gave effect to the primary and secondary legislation to the extent that this covered ground in the case, and, for the rest, relied on the concurrence of jurisdictions of various states under international law.

By 1973, as Akehurst was reporting, there were hardly any examples of other states objecting to the exercise of US antitrust jurisdiction as such, but protests were mainly related to the far-reaching orders made at the end of the case. US courts had the authority to make such farreaching orders. ${ }^{123}$ The United Kingdom objected to US extra-territorial jurisdiction in matters of antitrust. This, however, was not a case of the inherent illegality of such jurisdiction but merely one due to the position

119 Lord Diplock decided to 'allow Laker's appeals in both civil actions and discharge the injunctions granted by the Court of Appeal', ibid. 95; Lord Scarman also concluded that the airlines 'are not entitled to relief by way of injunction from an English court', ibid. 96.

120 Laker, n. 117 above, 185-6.

121 Lowe, n. 12 above, 267.

122 H.G. Maier, 'Extraterritorial Jurisdiction at a Crossroads: An Intersection between Public and Private International Law' (1982) 76 AJIL 280 at 299.

123 Akehurst, n. 2 above, 210. 
of Britain as persistent objector, potentially generating, at the very most, the lack of opposability of such jurisdiction to the United Kingdom rather than its illegality as such. ${ }^{124}$

\subsubsection{Some Controversial Uses of Extra-territorial Jurisdiction}

While, as we have seen, the US judiciary has at times been willing to moderate accordingly, the legislative and executive branches of the US government on other occasions have shown the political willingness to press extra-territorial jurisdictional exercises to further extremes, and use them as tools of political and economic pressure on other countries, as witnessed both by the Soviet gas pipeline-related controversies and the Helms-Burton Act. The US measures, such as those adopted under the 1992 Helms-Burton Act, among other things aiming to isolate Cuba from international economic relations, have purported to reach much further than any previous US assertion of extra-territorial jurisdiction in antitrust matters. The most pertinent feature of the Act perhaps is that it enables American citizens to recover compensation from any person who knowingly sells, transfers or distributes, or uses in commercial activities, or otherwise profits from such use of, property that the Castro government confiscated from American citizens from 1 January 1959 onwards (section 4 of the Act). As Lowe states in examining the merit of those claims:

The objectionable US jurisdictional claims here were not applications of the effects doctrine but were, rather, claims (1) to treat any company owned or controlled by US interests, whatever its nationality, as if it were a US company, and (2) to impress goods and technology originating in some sense in the United States with US nationality, so that transactions anywhere in the world involving them would be subject to US regulation. ${ }^{125}$

Another, earlier example was the attempt by the United States to impose an embargo on the supply by certain European companies of goods destined for use in the construction of the Soviet gas pipeline. The effect was to forbid the exportation to the USSR of specified oil and gas machinery in several different circumstances unless the permission of US authorities was first obtained. The ratione personae scope of those covered by these measures was rather broad including, under various

\footnotetext{
124 Cf. Lowe, n. 12 above, 257 at 264.

125 A.V. Lowe, 'US Extraterritorial Jurisdiction: The Helms-Burton and D’Amato Acts' (1997) 46 ICLQ 378.
} 
headings, persons who were present within the United States or were considered by the United States to be subject to US jurisdiction. ${ }^{126}$

The European Community's reaction to such broad US measures was that:

the so-called 'effects doctrine', under which conduct occurring outside the territory but causing direct, foreseeable and substantial effects - which are also constituent elements of a crime or tort - within the territory may be proscribed [has found less than general acceptance under international law]. ... The 'effects doctrine' is not applicable. It cannot conceivably be argued that exports from the European Community to the U.S.S.R. for the Siberian gas pipeline have within the U.S.A. direct, foreseeable and substantial effects which are not merely undesirable, but which constitute an element of a crime or tort proscribed by U.S. law. It is more than likely that they have no direct effects on U.S. trade. ${ }^{127}$

It is possible to see the EC's approach here as a nuanced one, presumably eschewing definitive condemnation of the effects doctrine and attacking US measures as ones that could not be based on transparently demonstrable effects within the US territory. This position thus shows the understanding of the effects doctrine proper. The EC position is therefore a useful contribution to state practice, in the sense that it requires drawing a clear distinction between the effects jurisdiction proper and the use of extra-territorial jurisdiction for political purposes only.

This demonstrates that, for the purposes of the legality of the assertion of jurisdiction, extending state jurisdiction to foreign nationals active in foreign countries is not the same thing throughout, in terms of the legality as well as practicability of underlying jurisdictional measures. It also stands to reason that the ultimate legality of these pertinent US measures would turn on the legality of the underlying boycott, not inherently on the nature of jurisdiction that has been asserted.

In sum, the reactions and protests against particular exercises of state jurisdiction should be seen through the general prism of state practice as part of the process of the creation and development of customary

126 As discussed in A.V. Lowe, 'Public International Law and the Conflict of Laws: The European Response to the United States Export Administration Regulations' (1984) 33 ICLQ 515 at 516-17; the jurisdiction seemed to have been asserted 'over US technology and its fruits wherever it or they might be', ibid. 517-18.

127 Comments on the Amendments of 22 June 1982 to the Export Administration Regulations (1982) 21 ILM 891, paras 12-13. Sanctions imposed on European companies under the regulations were lifted in November 1982, see Lowe, n. 126 above, 519. 
international law. Generally speaking, reactions and protests can have varying and diverse targets they react to, and the same applies to the object and means of the very measure of objection and protest. They could be against jurisdiction as such, its particular exercise, its reach, or merely be constrained to refusals to assist or support in any manner the exercise of the jurisdiction which is seen as unlawful, or otherwise objectionable or undesirable. Reciprocal measures may possess the character of countermeasures or reprisals, or be a mere retorsion. They may further be directed at foreign governments or entities, or at entities operating within the relevant state's domestic realm, whether national or foreign. This way, reciprocal measures of reaction may be ones relating to, and thus material for the legality of, jurisdiction as such, or ones relating to issues other than jurisdiction, such as enforcement of judgments and other issues of mutual inter-state legal cooperation. The precise scope of, and intention behind, the particular state reaction would then determine its precise contribution to state practice on these matters.

\subsection{UNIVERSAL JURISDICTION: CIVIL AND CRIMINAL}

\subsubsection{General Relevance}

From now on, our analysis will move on to one further particular heading of state jurisdiction which does not require the demonstration of any link to persons subjected to jurisdiction. This is universal jurisdiction over the perpetrators of core international crimes, such as torture, genocide, war crimes and crimes against humanity. Under customary international law, universal jurisdiction in relation to such proceedings is justified by reference to the community interest - separate from the interest individual states might have in the particular matters - in prosecuting relevant core international crime.

\subsubsection{Universal Jurisdiction in Criminal Proceedings}

Universal jurisdiction is exercised over the relevant crime in the absence of a connection point between that crime and the forum state. It is generally acknowledged that such universal jurisdiction currently exists over war crimes, crimes against humanity, torture and genocide. The 2005 Resolution of the Institute of International Law perceives universal jurisdiction as the primary tool for combating international crimes. As the 
Preamble to the Resolution states, the primary responsibility for combating these crimes lies with individual states. The Preamble proceeds to affirm that 'universal jurisdiction is an additional effective means to prevent impunity for international crimes'. Article 1 of the Resolution states that 'Universal jurisdiction in criminal matters, as an additional ground of jurisdiction, means the competence of a State to prosecute alleged offenders and to punish them if convicted, irrespective of the place of commission of the crime and regardless of any link of active or passive nationality, or other grounds of jurisdiction recognized by international law'. Most significantly, Article 2 affirms that 'Universal jurisdiction is primarily based on customary international law'. The following articles specify the crimes to which universal jurisdiction applies. ${ }^{128}$

In England, the House of Lords in Pinochet clarified that universal jurisdiction is available in case of breaches of jus cogens, having demonstrated the clear link between the two notions. ${ }^{129}$ The decision of the Australian Supreme Court in Polyukovich also suggests that universal jurisdiction 'is based on the notion that certain acts are so universally condemned that, regardless of the situs of the offence and the nationality of the offender or the victim, each state has jurisdiction to deal with perpetrators of those acts'. ${ }^{130}$ Another Australian decision in Nulyarimma affirms that the customary jus cogens crime of genocide empowers all states to exercise jurisdiction over it. It was considered established that the crime of genocide 'has acquired the status of jus cogens or peremptory norm' and consequently 'States may exercise universal jurisdiction over such a crime'. This has been the legal position since at least 1948.131 Finally, the International Criminal Tribunal for former Yugoslavia (ICTY) in Furundzija affirmed that perpetrators of torture could be held criminally responsible for torture, whether in a foreign state, or in their own state under a subsequent regime. It further specified, without referring to

128 Universal Criminal Jurisdiction with regard to the Crime of Genocide, Crimes Against Humanity and War Crimes (International Law Institute Krakow Session, 2005).

129 Crimes implicating breaches of jus cogens justify states in taking universal jurisdiction over them wherever committed, because offenders are common enemies of mankind and all nations have an equal interest in their apprehension and prosecution, per Lord Browne-Wilkinson, Pinochet [1999] 2 All ER 109; per Lord Millett, ibid. 177-8. See also Court of First Instance of Brussels (1999) 119 ILR 356-7.

130 Polyukhovich v Commonwealth (1991) 91 ILR 118 (per Toohey J).

131 Nuliarimma (1999) 165 ALR 621 at 632 (per Whitlam J); 641 (per Merkel J). 
any territorial or nationality link to the crime, that 'one of the consequences of the jus cogens character bestowed by the international community upon the prohibition of torture is that every State is entitled to investigate, prosecute and punish or extradite individuals accused of torture, who are present in a territory under its jurisdiction'. The inherently universal character of the crime based on its peremptory status gives all states universal jurisdiction. ${ }^{132}$

In 2002, the conclusion that was reached by Judges Higgins, Kooijmans and Buergenthal in the Arrest Warrant case was therefore somewhat counter-factual, to the effect:

That there is no established practice in which States exercise universal jurisdiction, properly so called, is undeniable ... This does not necessarily indicate, however, that such an exercise would be unlawful ... [For] a State is not required to legislate up to the full scope of the jurisdiction allowed by international law ... National legislation may be illuminating as to the issue of universal jurisdiction, but not conclusive as to its legality. ${ }^{133}$

As it happens, there was already a significant amount of practice at the time when the three judges wrote their Joint Separate Opinion. But more substantial is their main point, similar to the one made in Lotus, both in terms of the initial freedom to act in the exercise of jurisdiction in the absence of a prohibitive rule, and also in terms of how the court in Lotus declined to see the examples from state practice as an undeniable indication as to whether the relevant jurisdictional entitlement was or was not in place. The inconclusiveness of state practice is not an indication of a lack of jurisdictional entitlement of the state. Consequently, the universal jurisdiction over serious international crimes flows from grounds other than its recognition in individual situations in practice.

From the above analysis, it seems that there are three grounds that validate the existence and exercise of universal jurisdiction in international law. The first ground relates to the principles stated in Lotus. The second ground is the multiple recognition in conventional law which makes it possible for the customary rule against universal jurisdiction to materialize and gain effect. Examples could be furnished by reference to Articles 5 and 7 of the 1984 UN Convention Against Torture. Similar effect follows from Articles 49, 50, 129 and 146 of the 1949 Geneva Conventions which oblige states to search for and try persons accused of

132 Furundzija, Case no. IT-95-17/I-T, ICTY, Judgment of 10 December 1998, paras 155-6.

133 Arrest Warrant, n. 46 above, para. 45. 
grave breaches of these Conventions. The same obligation is extended to breaches of Additional Protocol I under its Article 85. The Geneva Conventions impose on states parties obligations that require a more proactive action in terms of searching for offenders and establishing jurisdiction over them. The third ground for universal jurisdiction is jus cogens. These three grounds are not always mutually overlapping, but universal jurisdiction can be justified on each of those grounds separately.

The exercise of universal jurisdiction in practice has met support as well as a backlash. To illustrate, Belgium's amendment of its universal jurisdiction law, with more enhanced requirements as to the relevant person's presence on the Belgian territory, ${ }^{134}$ was caused by completely non-legal factors, such as pressure from the US government, including the threat that Belgium would cease to be the host of the NATO headquarters. Also, the US pressure was based not on legal conviction but on practical concerns not to have its officials prosecuted in Belgium.

\subsubsection{Two Related Points: The Presence of the Accused and the Duty to Prosecute}

As we saw above, the dissent of Judge Guillaume in Arrest Warrant required the presence of the accused on the territory of the state before that state could try that person for core international crimes. This position was impliedly but effectively contradicted by the Court's majority in Arrest Warrant where, in the first place, the universal jurisdiction was not disputed by the respondent state even as it was exercised in the absence of the accused. Then, the International Court has at least implicitly recognized universal jurisdiction over serious international crimes, as it joined the parties in not disputing its existence; furthermore, the Court stated that one state can try another state's foreign minister after his/her retirement and did not specify that any territorial or nationality link was required either with the accused or the victim. ${ }^{135}$ The Joint Separate Opinion has further endorsed this position in the sense that:

National legislation, enacted to give effect to these treaties, quite naturally also may make mention of the necessity of the presence of the accused. These sensible realities are critical for the obligatory exercise of aut dedere aut prosequi jurisdiction, but cannot be interpreted a contrario so as to exclude a voluntary exercise of a universal jurisdiction. ${ }^{136}$

\footnotetext{
134 (2003) 42 ILM 1258.

135 Arrest Warrant, n. 46 above, para. 61.

136 Ibid., Joint Separate Opinion, para. 57.
} 
More generally, it cannot be asserted that the exercise of any extraterritorial jurisdiction, including the nationality-based jurisdiction, inherently requires the presence of the accused within the forum state's territory as a criterion validating that jurisdiction. There is no reason why that should be seen as a requirement specifically applicable to universal jurisdiction.

This discourse also raises the issue of the difference between the duty to prosecute core international crimes and the type of jurisdiction established, for that purpose, over the same crimes. A treaty imposing the duty to prosecute particular crimes may establish a completely new jurisdiction hitherto inapplicable to the relevant crime, or broaden an existing one under general international law, or actually reflect the pre-existing headings of jurisdiction and make them mandatory. It seems that the latter possibility is envisaged in the provisions of the 1984 Convention Against Torture (CAT) and the Geneva Conventions 1949, referred to above.

More broadly speaking, the duty to prosecute is not as much about establishing a particular jurisdictional entitlement as about turning its exercise into a duty. This could be in relation to any type of territorial or extra-territorial jurisdiction, universal or other. In addition, as the Joint Separate Opinion has also emphasized, the conventional duty to prosecute or extradite can require establishing jurisdiction with a view to extraditing or prosecuting: the aim is that the offender should be prosecuted within the spatial remit of the treaty-established jurisdictional network and that there should be no safe haven or impunity for the offender to benefit from. In the view of the three judges:

The stated purpose of the provision was that the offences would not be left unpunished (the extradition provisions playing their role in this objective). It may immediately be noted that this is an early form of the aut dedere aut prosequi to be seen in later conventions. But the obligation to prosecute is primary, making it even stronger. ${ }^{137}$

137 Ibid. Joint Separate Opinion, 71 (para. 30). 


\subsubsection{Universal Jurisdiction in Civil Proceedings}

Since the landmark judgment in Filartiga, ${ }^{138}$ the US Alien Tort Statute (ATS) ${ }^{139}$ has for decades been applied by US courts to violations of international law perpetrated outside the territory of the United States and committed by foreign citizens against foreign victims, provided that, in line with jurisprudence culminating with Sosa, the cause of action relied on a 'universal, definable and obligatory' norm of international law. ${ }^{140}$ In more express terms, as to the normative basis of universal civil jurisdiction, was the Canadian Court of Appeal in Bouzari, which has recognized universal civil jurisdiction over the breaches of peremptory norms. Since by torturing Bouzari Iran had committed a breach of peremptory norms, it eliminated itself as a possible forum; the appellant was left without a forum and hence the application of the requirement that the tort must have a real and substantial connection with the forum was not easy. ${ }^{141}$

According to Article 14(1) of the CAT 1984, 'Each State Party shall ensure in its legal system that the victim of an act of torture obtains redress and has an enforceable right to fair and adequate compensation'. This clause includes no restriction ratione loci. Redress should be made available to any victim of torture, regardless of the locus of the act. ${ }^{142}$

In Bouzari before the Canadian Court of Appeal, and Jones before the UK House of Lords, this extra-territorial effect was not accepted, not because the relevant national courts denied the inherent potential of Article 14 to displace immunities, but because Article 14 was seen to

\footnotetext{
138 Filartiga v Pena-Irala, US Court of Appeals, Second Circuit, (1980) 77 ILR 169.

139 ATS s. 1791 provides that 'The district courts shall have original jurisdiction of any civil action by an alien for a tort only, committed in violation of the law of nations or a treaty of the United States'.

140 Sosa v Alvarez-Machain, No. 03-339, 29 June 2004.

141 Bouzari v Islamic Republic of Iran, Court of Appeal for Ontario, 30 June 2004, Docket: C38295, paras 36-8, per Goudge JA; although the court stated in para. 38 that it did not need to finally clarify this issue because the adjudication was refused on the basis of state immunity, which is an issue separate from the issues of jurisdiction.

142 See for detailed analysis of Article 14 of the CAT, C.K. Hall, 'The Duty of States Parties to the Convention Against Torture to Provide Procedures Permitting Victims to Recover Reparations for Torture Committed Abroad' (2007) 18 EJIL 921.
} 
relate only to torture committed within the forum state's territory. ${ }^{143}$ But the UN Committee Against Torture has confirmed, in the aftermath of Bouzari, that the scope of Article 14 is not limited to torture committed within the forum state's territory. ${ }^{144}$

More recently, the Committee's General Comment No. 3 specified that 'the application of Article 14 is not limited to victims who were harmed in the territory of the State party or by or against nationals of the State party'. ${ }^{145}$ The duty to implement Article 14 in line with General Comment No. 3 has been reiterated in relation to the United Kingdom specifically. ${ }^{146}$

National courts in Bouzari and Jones have, therefore, effectively engaged in a unilateral interpretation of Article 14, reading in a limitation that is not there. That the Committee's views are not inherently binding is, quite simply, immaterial. The Committee has been set up through the agreement of all states parties to the CAT and is, on that basis, in charge of implementing the Convention. Its views as to its content are supposed to be more authoritative than those of states parties put forward unilaterally. This is all the more obvious if all the Committee has done, in relation to both Canada and the United Kingdom, is to reaffirm the duty of both states to act in line with the plain and ordinary meaning of the obligation contained in Article 14.

\subsubsection{Universal Civil Jurisdiction and the Kiobel Case}

According to the Supreme Court in Kiobel, ${ }^{147}$ the ATS that was at the forefront of the development of state practice regarding universal civil jurisdiction in this area, will only apply to whatever takes place within the United States, because in enacting the ATS, the Congress must be deemed to have so intended. The Court's principal point related to a presumption against extra-territoriality of legislative enactments. The

143 Bouzari v Islamic Republic of Iran, n. 141 above, paras 72-82 (per Goudge JA); Jones v Saudi Arabia [2006] UKHL 16, 14 June 2006, para. 20 (per Lord Bingham); para. 46 (per Lord Hoffmann).

144 UN Committee Against Torture, Observations of the Report of Canada, $\mathrm{CAT} / \mathrm{C} / \mathrm{CO} / 34 / \mathrm{CAN}$, paras $4(\mathrm{~g})$ and $5(\mathrm{f})$.

145 UN Committee Against Torture, General Comment No. 3 (2012), para. 22.

146 Concluding Observations on the Fifth Periodic Report of the United Kingdom, adopted by the Committee at its 50th Session, 6-31 May 2013, para. 17.

147 Kiobel v Royal Dutch Petroleum, US Supreme Court, No. 10-4091, Judgment of 17 March 2013. 
Supreme Court referred to two incidents in the late eighteenth century, before the adoption of the ATS, and involving foreign ambassadors, which allegedly reinforced such a restricted meaning of the ATS. While piracy was ordinarily understood to be within the scope of the ATS, it was singled out as a special category not affecting the otherwise applicable presumption against extra-territoriality. ${ }^{148}$

A further policy argument was to deny that 'the ATS was passed to make the United States a uniquely hospitable forum for the enforcement of international norms'.149 Conversely, American citizens should be spared similar risks of being impleaded in foreign countries. The concurring opinion of Justice Breyer discussed alternatives to the majority's approach, enabling courts to assume a greater role in this process, such as the forum non conveniens doctrine or the balancing of underlying interests, including the relevance of the defendant's presence in the United States. Justice Breyer also warned against the United States becoming a safe haven for international criminals. ${ }^{150}$

The starting-point for the majority's approach to statutory interpretation was that 'when a statute gives no clear indication of an extraterritorial application, it has none', and 'when a statute provides for some extraterritorial application, the presumption against extraterritoriality operates to limit that provision to its terms'. This thesis is questionbegging. If, as the Court accepts, 'a statute provides' for its own extra-territoriality, how can the Court's presumption against extraterritoriality limit its relevant provisions 'to its terms'? For, those 'terms' are the only means through which the Congress can manifest the intention for providing 'some extraterritorial application' of its enactments. Conversely, the common law presumption against extraterritoriality would have no independent value if it only 'operates to limit that [legislative] provision to its terms'.

As it happens, it was precisely the ambit of those very 'terms' that the Supreme Court's majority trimmed down through the use of the abovementioned legislative presumption. As the majority argued:

nothing in the text of the statute suggests that Congress intended causes of action recognized under it to have extraterritorial reach. The ATS covers actions by aliens for violations of the law of nations, but that does not imply extraterritorial reach - such violations affecting aliens can occur either within or outside the United States. Nor does the fact that the text reaches 'any civil

\footnotetext{
148 Ibid. 5-14.

149 Ibid. 12.

150 Ibid., Concurring Opinion, 7-15.
} 
action' suggest application to torts committed abroad; it is well established that generic terms like 'any' or 'every' do not rebut the presumption against extraterritoriality. ${ }^{151}$

The Court supported this approach by referring to Amerada Hess, where a clause in the Foreign Sovereign Immunities Act 1976 (FSIA) was construed as lacking extra-territorial application; ${ }^{152}$ even though the relevant clause in the FSIA (section 1605(a)(5)) expressly refers to acts committed in the United States, while the ATS contains no similar limitation. Moreover, the ATS includes the words 'any' and 'every' in relation to the law of nations which is ordinarily concerned with issues arising from occurrences that take place abroad.

Subscribing in Kiobel to this blanket presumption, in principle superimposing it on all statutes, rather than applying each statute according to its ordinary meaning, is an entirely judicial choice. The Congressional intent was further compromised by reliance being placed on two pre-ATS incidents that happened before the Congress formed its legislative intention. Surely, for the purposes of statutory interpretation, the Congressional will must be seen as that of an institution which can form its intent independently of some antecedent occurrences and incidents, that intention then to be recorded on statute books accordingly.

On piracy in particular, the Court's argument was that 'pirates may well be a category unto themselves' and that:

Applying US law to pirates, however, does not typically impose the sovereign will of the United States onto conduct occurring within the territorial jurisdiction of another sovereign, and therefore carries less direct foreign policy consequences..$^{153}$

Here, the otherwise applicable presumption against extra-territoriality suddenly disappears. In reality, piracy is but one instance of the ATS extending to extra-territorial activities. It is, again, an entirely judicial choice to imply the presumption against extra-territoriality in respect of some provisions of the statute but not to others; and an approach that cannot make straightforward sense of what legislative intention Congress had in enacting the ATS. After all, if the Congress did not want the ATS to be extra-territorial and if the relevant presumption is so strong that not even the words 'any' and 'every' will rebut it, then that legislative

\footnotetext{
$151 \quad$ Ibid. 7.

152 Argentine Republic v Amerada Hess Shipping Corp., 109 S.Ct. 683
} (1989).

153 Kiobel, n. 147 above, 10. 
intention must be respected and piracy too must be excluded from the ambit of the ATS.

The policy justification for construing the ATS so narrowly was that ATS litigation may involve a judicial interference into 'a delicate field of international relations', which must be affirmatively mandated by the Congress so 'that the Judiciary does not erroneously adopt an interpretation of US law that carries foreign policy consequences not clearly intended by the political branches'. ${ }^{154}$ However, presupposing that US courts will erroneously interpret US law is a highly problematic approach: jura novit curia.

Similarly, the Kiobel point on whether 'other nations, also applying the law of nations, could hale our citizens into their courts for alleged violations of the law of nations occurring in the United States, or anywhere else in the world' is, quite simply, a matter of public international law entitlement of those other states to exercise their jurisdiction whenever the relevant link or nexus to the particular matter is present. The Supreme Court's presumption against extra-territoriality, a creature purely of US domestic law, and also hardly compatible with previous assertions of extra-territoriality in antitrust matters, could do precious little to upset that possibility. All in all, there is no such thing as a perfectly harmonious world in international relations and, even if there were one, the judiciary would not be best suited to determine exactly what it might look like.

\subsection{CONCLUSIONS}

The most important general conclusion to be drawn from the above analysis is that public international law provides states with a rather broad initial freedom to assert jurisdiction over a particular matter within the framework of concurrence, subject to any particular prohibitive rule of international law, or one that redistributes, inter se, the jurisdiction available under general international law. On the plane of general international law, the only visible restrictions are the requirement of a proper link, or nexus, with underlying events (with the exception of universal jurisdiction), and the prohibition of abuse or vexatious use of jurisdiction.

This chapter has proposed to view jurisdiction of states in terms of the overarching systemic framework under international law that determines

154 Ibid. 4. 
both the propriety and feasibility of the exercise of national jurisdiction. From there, we can have coherent answers as to right and wrong in jurisdictional controversies. Perhaps the most important lesson furnished by practice is that there is no feasible difference, in terms of general public international law, in terms of the assertion by states of civil and criminal jurisdiction; where there is criminal jurisdiction there is a civil one as well, as a matter of state entitlement at least; whether it is being exercised in practice does not prejudice the issue of whether it exists and could be exercised. It is state entitlement, and the connection between the state and the matter covered by jurisdiction, which matters for the existence of jurisdiction, not the particular type of judicial proceedings. That in some cases criminal and in other cases civil jurisdiction is regulated under various treaties, in a rather complex and detailed manner, is only an issue of special regulation that establishes a situational and empirical distinction from general international law, not a general position under it. 